\title{
CONCURRENT BANKRUPTCIES AND CREDITOR EQUALITY IN THE AMERICAS *
}

\author{
By KuRT H. NAdelmann $\dagger$
}

Creditor equality, the par conditio creditorum, ${ }^{1}$ is the basic principle which governs the bankruptcy law in all American nations. As the Supreme Court of the United States has said, "equality between creditors is necessarily the ultimate aim of the bankrupt law." 2 No discrepancy of views exists as to that in the Americas. The differences begin when it comes to the implementation of the principle in one instance-the case of concurrent bankruptcies.

Coexistence of bankruptcy proceedings against the same debtor in two or more countries is not infrequent. Notably when a debtor is engaged in international trade, his property is often dispersed over several countries. The court of the domicile of the debtor is not the only one with bankruptcy jurisdiction. Some countries assume bankruptcy jurisdiction when a non-resident has a business establishment or a branch in the country or carries on business there. In other countries, the presence of assets is sufficient to entitle the court of the location to assume bankruptcy jurisdiction. In some places, the courts deliver the local assets to the foreign domiciliary trustee in bankruptcy. In some countries, the law forbids, or does not provide for, such transfer of the local assets, irrespective of whether the rights of the local creditors are protected abroad and whether duplication of the proceedings is in the interest of the creditors; local distributions are thus necessary.

The special problems created by concurrent bankruptcies require a proper solution. A creditor involved in a failure dealt with in two or more proceedings may present his claim in all of them. It is of interest to know what rules are in effect in American countries with regard to the admission and payment of claims in such instances. The rules which could be traced are noted in this survey and discussed critically from the viewpoint of creditor equality.

* The substance of this article was originally presented in a paper read before the Fifth Conference of the Inter-American Bar Association, Lima, Peru, 1947.

$\div$ J. U. D., Freiburg in Breisgau, 1921; Lic. en Dr., Paris, 1934. Lecturer in Comparative Law, University of Pennsylvania. Reporter on "Bankruptcy", Second International Congress of Comparative Law, The Hague, 1937. Author of The National Bankruptcy Act and the Conflict of Lazes, 59 HARv. L. REv. 1025 (1946); Bankruptcy Treaties, 93 U. OF PA. L. REv. 59 (1944) and 9 REvisTA DE LA EscuELA NACIONAL DE JURISPRUDENCIA, No. 35 (Mexico, 1947); and of other articles in legal periodicals.

1. Digest 42. 8. 6. 7.

2. Clarke v. Rogers, 228 U. S. 534, 548 (1913). 
Canadian courts ${ }^{3}$ follow a rule developed in the English courts ${ }^{4}$ called the hotchpot rule, which provides that a creditor, who has recovered payment abroad and wants to prove in the domestic bankruptcy for any further claim he may have, must throw into the common fund what he has received in the foreign country. In other words, his share is calculated on the basis of an estate in which the money recovered abroad is included. The rule is derived from the equity maxim "He who asks for equity must do equity." 5

The principle secures equal treatment to all from the viewpoint of the domestic law. Because of differences in the domestic and the foreign law the percentage reverting to the individual creditor may not be the same at home and abroad, even assuming scrupulous application of the rule at both places. A claim may have a priority ranking under the foreign law which it does not have under the domestic. In some countries wages have a priority for a period covering the last six months, in others for a period which is shorter or longer. Or, because of a different counting of the "critical" period in both laws, an attachment made before bankruptcy may not be void under the foreign law, but may be void under the domestic. As each court follows its own distribution rules, only complete uniformity of the bankruptcy laws could secure equal results in all circumstances.

The principle of equalization as expressed in the hotchpot rule is the law also in the United States. The National Bankruptcy Act prescribes the marshalling of the assets, ${ }^{6}$ and the courts have applied the principle also in insolvent estate matters not covered by the National Bankruptcy Act. ${ }^{7}$ State legislation that discriminates against citizens of other States of the Union has been declared unconstitutional by' the Supreme Court of the United States. ${ }^{8}$

3. Cf. Duncan and Reilley, Bankruptcy in Canada 579 (2d ed. Toronto 1933); de la Durantaye, Traité de la Failitte, No. 59 (Montreal 1934).

4. Banco de Portugal v. Waddell, 5 App. Cas. 161 (1880). Cf. Lord Eldon's dictum in Selkrig v. Davies, 2 Dow's Reports 230, 249, 3 English Reprints 848, 855 (H. L. 1814, appeal from Scotiand). See CHESHIRE, PRIVATE INTERNATIONAL LAW 487 (2d ed. Oxford 1938); Westlake, Traite dE Droit International Prive 222 (Goulé trans., Paris 1914).

5. Sneld, Princtrles of Eluity 292 (22d ed. London 1939) ; Wolff, Private INTERNATIONAL LAW 573 (Oxford 1945).

6. United States Bankruptcy Act, 1898, §65(d), 30 Stat. 564 (1898), 11 U. S. C. $\$ 105$ (d) (1940). Cf. 3 CoLLIER, BANKRUPTCY $\$ 65.05$ (14th ed. 1941).

7. Restatement, Conflict of Laws $\$ 503$ (decedent estates), $\$ 560$ (receiverships) (1934); Exposé dU DrotT INTERnatIonal PRIVÉ AMÉRICAIN PRÉsENTÉ EN FORME DE CODE PAR I'AMERICAN LAW INSTITUTE \$\$ 503, 560 (Pierre Wigny and J. Brockelbank trans., Paris: Sirey 1938); 3 BEALE, Conflict of LAws $\S 501.1,554.1$ (1935).

8. Blake v. McClung, 172 U. S. 239 (1898); cf. Goodrich, Handbook of the Conflict of Laws 521 (2d ed. 1938). 
The way in which the marshalling of assets is prescribed in the National Bankruptcy Act is open to criticism on a technical point. Section 65 (d) of the Act provides: "Whenever a person shall have been adjudged a bankrupt by a court without the United States and also by a court of bankruptcy [i.e., within the United States], creditors residing within the United States shall first be paid a dividend equal to that received in the court without the United States by other creditors, before creditors who have received a dividend in such courts shall be paid any amounts". Only the creditors residing in the United States are thus brought under the protection of the equalization rule. It is difficult to see why the same protection should not revert also to creditors, domestic and others, residing in a third country who have been unable to cash a dividend in the foreign distribution. The differentiation is inconsistent with the principle of equal treatment of all creditors which governs the American bankruptcy law. ${ }^{9}$

\section{II}

Under the law of Mexico, the Mexican branch of a foreign enterprise may be declared bankrupt in Mexico notwithstanding the bankruptcy of the enterprise abroad. The new Bankruptcy Act of $1942^{10}$ provides that, in such a case, the bankruptcy in Mexico affects the assets in Mexico and the debts resulting from operations of the branch. This means in fact the creation of a priority on the Mexican assets for clients of the branch. This departure from the principle of creditor equality has been criticized by some authors. ${ }^{11}$

Of the Central-American Republics, Costa Rica seems to be the country with the earliest provisions on the effects of foreign bankruptcy adjudications. In 1865, Costa Rica took over the provisions of the bankruptcy code of Prussia. That code, which was adopted in $1855,{ }^{12}$ permitted a local bankruptcy over local commercial establishments and allowed levy of execution on the local assets in all other cases. Publication of requests from foreign trustees for local assets was prescribed. Costa Rica undertook a change in the system by allowing only resident creditors to levy execution. ${ }^{13}$ Costa Rica's Civil Code of 1886, presently in force, gives to residents a right of priority of payment in both circumstances, bankruptcy and individual execution for the local

9. Cf. Nadelmann, The National Bankruptcy Act and the Conflict of Laws, 59 HARV. L. Rev. 1025, 1049 (1946), 21 J. N. A. ReF. BANKR. 43, 51 (1947).

10. Bankruptcy Act of Dec. $31,1942, \S 13(3)$. Cf. JoAQUIN RodriguEz Y RodRIguez, Ley de Quiebras y Suspensión de Pagos 29 (Mexico D. F. 1943).

11. See Alberto M. Arce, Manuat de Derecho Internacional Privado MexiCANO 381 (1943).

12. Bankruptcy Code of May 8, 1855, $\$ \S 292-296$.

13. Bankruptcy Code of Oct. $3,1865, \$ \$ 256-260$. 
assets. ${ }^{14}$ According to another rule in the Code, assets acquired within the country are primarily not available for the satisfaction of debts contracted abroad before the debtor established himself in Costa Rica. ${ }^{15}$ For non-commercial matters, the Code of Civil Procedure has continued the priority rules of the law of $1865 .^{16}$ Regarding commercial bankruptcies, the Bankruptcy Act of 1901 provides that, for the right of priority of payment, "resident creditors" means (1) Costa Ricans, even when residing abroad, (2) foreigners having their domicile in Costa Rica at the time of contracting or of the execution of the transaction from which the claim arises. ${ }^{17}$

Except for this specification of "residence", Nicaragua has the same rules as Costa Rica. The provisions in the Civil Code ${ }^{18}$ and the Code of Civil Procedure ${ }^{19}$ are identical with those in Costa Rica. .

Panama has in its Code of Procedure the same procedural provisions as Costa Rica and Nicaragua, ${ }^{20}$ with the priority right for the resident creditors. The Commercial Code of 1916, the work of Luis Anderson of Costa Rica, contains an elaborate set of rules for commercial cases regarding the effects of foreign bankruptcy adjudications. Under the system, which is a combination of rules from the laws of Brazil and Argentina and the Montevideo treaty of 1889 , local creditors may ask for a local bankruptcy adjudication. In that bankruptcy they are paid first. "Local creditor" is defined as a creditor with a claim payable in Panama. Non-resident creditors are given equal rights when the debtor has transacted business abroad only occasionally, or has opened there a branch operated for the account of a principal establishment in Panama. ${ }^{21}$

Honduras has in its new Commercial Code of $1940^{22}$ provisions to the effect that if bankruptcy is declared abroad and the debtor has a branch or just assets in Honduras, a local liquidation takes place for the purpose of first satisfying the debts which "take effect" ${ }^{23}$ in the country and then those from abroad.

Haiti and the Dominican Republic have adopted the provisions of the French Code of Commerce. The construction given this Code in the French courts is thus of interest. The courts have held con-

14. Civil Code of April 26, 1886, $\$ 980$.

15. Civil Code, $\$ 983$.

16. Code of Civil Procedure of 1933, $\$ \S 648-651$.

17. Bankruptcy Act of Oct. 15, 1901, $\$ 10$.

18. Civil Code of 1904, $\$ \$ 2334$ and 2337.

19. Code of Civil Procedure of 1905, $\$$ 1951-1954.

20. Code of Procedure of 1916, $\$$ 1891-1894.

21. Commercial Code of 1916, $\$$ 1638-1648.

22. Commercial Code, Decree No. 118, of 1940, $\S \S 1057-1060$.

23. Que deben tener efecto. 
sistently, ${ }^{24}$ and leading authors agree, ${ }^{25}$ that a creditor cannot claim a share in the French bankruptcy if he does not account for the payments received in distributions abroad (the hotchpot rule). Except for this, he is entitled to his equal share in the French distributions. For the same reasons as given by the French courts, the right to prove in all proceedings on equal terms has been upheld also in the Italian courts ${ }^{28}$ and the Mixed Courts in Egypt. ${ }^{27}$

\section{III}

For a long time Brazil has had statutory rules on the recognition of the effects of a foreign bankruptcy adjudication. Under Lafayette Rodrigues Pereira as Minister of Justice, Brazil adopted in $1878^{28}$ a liberal system advocated at the time by the Italian professors Pasquale Fiore $^{29}$ and Guiseppe Carle. ${ }^{30}$ A difference is made between ordinary cases and cases where a debtor domiciled abroad has two distinct and separate establishments, one abroad and one at home. In the ordinary cases, recognition of the effects of the foreign bankruptcy may be secured in the local courts by way of an exequatur proceeding. Separate bankruptcies are admitted in case of the existence of separate establishments, and in that case the estates are treated separately.

The separation of estates in the case of different establishments goes back to a rule in the Digest ${ }^{31}$ which provides that when a slave

24. E. g., Appeal Paris, July 22, 1929, Banque Russo-Asiatique, 56 Journal du DroIt INTERNational 1116 (France 1929), 25 REVUE DE DroIT INTERNATIONAL Prrve 119 (France 1930) ; Appeal Paris, May 11, 1927, Banque Française pour le Brésil, 55 Journal du Drotr Internatronal 654 (1928); Com. Trib. Le Havre, July 4, 1898, Banco Italiano del Uruguay, 19 Journal DES FaIllites 278 (France 1900).

25. 8 Lyon-Caen \& Renault, Traite de Droit Commercial 833 (5th ed. with Amiaud, Paris 1936) ; 3 Percerou, Des Faillites Et Banqueroutes 272 (2d ed. with Desserteaux, Paris 1938).

26. Appeal Milan, March 23, 1923, Irving National Bank v. Dilsizian, 21 RrvisTA del Drritto Conimerciale, II. 400 (Italy 1923), 65 Monitore dei Tribunali 868 (Italy 1924). Cf. FIORE at Brussels, 1902, Session of the Institut de Droit International, 19 ANNUATRE DE L'INSTITUT 249.

27. Com. Trib. Alexandria, May 28, 1923, Vasdeki Frères, 14 GazetTe DEs TRIBunauX Mixtes D'Egypte 69 (No. 115) (Egypt 1923/24), 51 Journal DU DroIT InTERnational 1109 (France 1924), 65 Monitore deI Tribunali 556 (Italy 1924). Cf. 3 Wahl \& Malache, Tratté de Droit Commercial Egyptien 10 (Alexandria 1946).

28. Decree No. 6981 of July 27,1878 , $\S 14-19$. Reference to the Italian school in Lafayette's Report: [1878] Colleçao dAs LeIs 444 (Brazil).

29. Fiore, Diritto Internazionale Privato, No. 369 (Turin 1869), in the French edition at p. 565 (Pradier-Fodéré trans., Paris 1875), in the Spanish edition, vol. II, at p. 150 (García Moreno trans., Madrid 1878). Cf. FIoRE, DEL Fallimionto Secondo Il Diritto Privato Internazionale 20 (Pisa 1873). See, however, Fiore at Brussels, 1902, op. cit. supra note 26, at 246; the Institute did not adopt the distinction.

30. Carle, la Dottrina Giuridica del Fallimento nel Diritto InternazioNAIE Privato, No. 22 (Naples 1872), in the French edition (Dubois trans., Paris 1875), at p. 40, with criticism by Dubois in n. 49 .

31. Digest 14.4.5.15. 
operates distinct businesses for his master, the creditors of each business shall be considered separately in the distribution of the assets. The applicability of the rule has been a subject of controversy since the Middle Ages in the Roman law countries. ${ }^{32}$ The rule has disappeared with the modern codes as a principle of internal law. No differentiation is made when a debtor has more than one establishment within the country. $U_{p}$ to the last century, some courts in Europe applied the rule when separate establishments were located in different countries. ${ }^{33}$ A thorough discussion of the propriety of the rule took place in 1880 at the International Juridical Congress of Turin. Upon the recommendation of the Bankruptcy Committee, for which Guiseppe Carle, first a supporter of the rule, acted as reporter, ${ }^{34}$ the Congress decided not to include the rule in the principles for bankruptcy treaties which it adopted. ${ }^{35}$

In Brazil, the system taken over in 1878 remained in force almost unchanged until 1939. A major modification was the addition in 1890 of a provision which designated as creditors to be paid first in the bankruptcy of the distinct and separate establishment in Brazil those who have claims payable in Brazil. ${ }^{36}$ This rule was taken from the Montevideo Treaty of 1889 , which will be discussed later. Critics have pointed out that claims payable outside Brazil may be the responsibility of the establishment in Brazil, and that not all claims payable in Brazil are necessarily a liability of that establishment. ${ }^{37}$

The whole system has now been changed. The new Code of Civil Procedure of 1939 does not distinguish any more between "distinct and separate establishments" and other establishments. The Code provides that a foreign bankruptcy adjudication, even when clothed with the Brazilian exequatur, does not include in its effects an "estab-

32. See, e. g., Straccha, De Mercatura, Tractatus de Decoctorrbus, ultima pars 21 (1558); MANTICA, DE Contractibus, part II, ch. 23, 32 ; SALGado DE Somoza, LABYRINTHUS CREDitoruM, part I, ch. 9, 53, part II, ch. 12, 73 (1646) ; RodeNBURgH, DE JuRE qUOD ORITUR eX Statutorum vei Consuetudinum Diversitate, part II, ch. 5, 16; J. Voet, Commentarius ad Pandectas, 14.4 .7 (1704) ; Brunnemans, De Processu Concursus Creditorun, part I, 1 (Stryk ed. 1668).

33. Appeal Brussels, June 6, 1816, Outhwaites Frères, London and Brussels, reported in MERLIN, REPERTOIRE DE JURISPRUDENCE, FAIILITE, section II, ch. II, Art. X, No. 2.

34. See Carle, II Fallimento nei Raprorti Internazionali: Relaztone PREsentata al Secondo Congresso Giuridico Italiano Internazionale in Torino 75 , n. 42 (Turin 1880). Cf. Gemma, Appunti di Diritto Internazionale Privato 304 (Padua 1936).

35. 7 Journal du Drotr International 625 (France 1880).

36. Decree No. 917 of Oct. 24, 1890, §98(3), continued in Bankruptcy Law No. 5746 of 1929 , $\$ 161$ until 1945 when that law was replaced by the new Bankruptcy Law No. 7661 of June 21, 1945 . On the earlier law, see 3 TraJano DE MIRANDA Valverde, A Falencia no Diretro Brasiletro 339 (Rio de Janeiro 1933).

37. E. g., Miranda Valverde, Anteprojeto de Lei de Falências, 99 Revista Forense 604 (Brazil 1944). 
lishment" that the bankrupt owns in Brazil. ${ }^{38}$ This amounts to an elevation of branches without separate standing to the status of autonomous establishments for the purpose of creditor satisfaction, a measure based, according to a commentator, on interests of national policy rather than on juridical grounds. ${ }^{30}$ The provision which declared that the claims payable in Brazil were those endowed with the right of priority of payment has not been incorporated in the Code of Civil Procedure which, since a change in the bankruptcy legislation effected in 1945, is the exclusive source of statutory law on the subject. While, in its general law, Brazil has thus given up the doctrine of the "distinct and separate establishments" for a broader local priority policy, it continues to apply the old system in its relations with the cosignatories of the Bustamante Code,

The bankruptcy rules of the Bustamante Code of Private International Lazw, adopted in 1928 at Havana by the Sixth Conference of American States, are based on the "separate establishments" doctrine. Lafayette Rodrigues Pereira had used that doctrine in his draft of 1911,40 and Judge Bustamante gave preference to this draft over one based on the system of the treaty of Montevideo of 1889, which he thought was not in accord with modern developments. ${ }^{41}$ Under the Bustamante Code, separate bankruptcies may be declared when "economically entirely different separate commercial establishments" exist in different countries. Otherwise, one single bankruptcy takes place at the domicile of the debtor with effect everywhere. ${ }^{42}$ The Montevideo rule separating claims according to the place of payment is not incorporated in the Code which does not deal specifically with the problem of separating the claims in the case of entirely separate establishments.

The Bustamante Code has been ratified by all Latin American countries except Mexico, Colombia, Uruguay, Paraguay, and Argentina. Some of the countries seem to apply the rules of the Code even in non-treaty cases.

38. Code of Civil Procedure, §788. Cf. Oscar Tenório, Direito Intrernacional Privado 388 (São Paulo 1942).

39. 3 Amfericano, Comentarios ao Código de Processo Civil do Brasil 292 (São Paulo 1942).

40. Lafayette Rodrigues Pereira, Projecto de Código de Direito Internacional Privado, \$115, 2(A) PANDECTaS BrasileIRAS 127 (Espinola ed., Rio de Janeiro 1927).

41. See Antonio S. de Bustamante y SiRvén, La Conisión de Jurisconsultos DE Rio de JANEIRo Y el Derecho INTERNACional, No. 187 (Havana 1927).

42. Bustamante Code, $\$ \$ 414-422,86$ League of Nations Treaty Series 362 (1929), The International Conferences of AMrerican States 1889-1928, 367 (Washington 1931), CONFERENCIAS INTERNACIONALES AMIERICANAS 1889-1936, 304 (Washington 1938). See 3 Antonio S. DE Bustamante y Sirven, Derecho InTer2Nacional PrIvado, No. 1885 (2d ed., Havana 1934). The European bankruptcy treaties have not adopted the distinction. Cf. Nadelmann, Bankruptcy Treaties, 93 U. of PA. L. Rev. 58 (1944), Spanish version in 9 Revista dE LA Escuela Nacronal dE JuRISPRUDENCIA, No. 35 (Mexico 1947). 


\section{IV}

Argentina, ${ }^{43}$ Uruguay, $^{44}$ and Paraguay ${ }^{45}$ have had in their bankruptcy law since 1862,1866, and 1903, respectively, the following provision: "The bankruptcy also declared by the courts of the Republic shall not take into account the creditors belonging to the foreign bankruptcy, except if a surplus remains after payment in full of the creditors in the Republic". This rule, which gives resident creditors priority rights in the case of concurrent bankruptcies, was also introduced in Peru, ${ }^{46}$ in 1932, together with another rule to the effect that debts contracted abroad are admitted on an equality basis only to the extent to which the funds were employed in an enterprise in Peru.

The rule which gives the resident creditor priority in the case of concurrent bankruptcies comes from the Commercial Code of 1859 for the Province of Buenos Aires, ${ }^{47}$ the work of Acevedo and Vélez Sarsfield. It does not seem to be established where this rule was taken from by the drafters. The local law of the time, the Ordinances of Bilbao, had no such rule, which remained alien also to later Spanish law. ${ }^{48}$ Massé's treatise on commercial law has been the source of another conflicts rule incorporated in the Code of 1859 , namely, the provision that the rights of domestic creditors shall not be affected by a foreign bankruptcy adjudication. ${ }^{49}$ It is not suggested by Massé, however, that resident creditors be given priority rights in all cases of concurrent bankruptcies; only the case of separate establishments is dealt with and a case is referred to wherein a Brussels court had decided in favor of the separate handling of the separate estates. ${ }^{50}$ In a work available when the Code of 1859 was drafted, the rule giving resident creditors priority rights in concurrent bankruptcies was listed as that of Prussia. This work, a compilation of foreign commercial codes in French language published by de Saint-Joseph in Paris in $1851,{ }^{51}$ summarizes the

43. Bankruptcy Law No. 11,719 of $1933, \$ 7(2)$. 1 CAstillo, LA QUIEBRA EN EL Derecho Argentrino, No. 103 (Buenos Aires 1940), and authors referred to later.

44. Commercial Code, \$1577. 1 Scarano, Tratado DE LA QuIEbra 210 (Montevideo 1939).

45. Commercial Code, $\$ 1383$.

46. Bankruptcy Law No. 7,566 of 1932, $\$ 26(2)$ and (3). Manuel SancHez Palacios, Ley Procesal de QuTEbras 20 (Lima 1939).

47. Section 1531. Cf. Almancro Alcorta, Fuentes y Concordancias del Cóprgo de Comercio, $\$ 1531$ (Buenos Aires 1887).

48. The only provision on the subject in the Ordinances of Bilbao of 1737 is the order in Chapter $17, \S 51$, to claim assets located abroad by way of rogatory letters.

49. 2 Massé, Le Droit Commerctal dans ses Rapports avec le Drott des Gens, No. 809 (Paris 1847).

50. No. 810, referring to Brussels, June 6, 1816, note 33 supra.

51. Antoine de Saint-Joseph, Concordance entre les Codes de Commerce Etrangers et le Code de Commerce Français 120 (Paris 1851); 2 Levi, ComMERCIAI LAW OF THE WORLd 357 (London 1852). For the law of Prussia as a source of the Argentine Civil Code, see Pedro León, El Código de Prusia como fuente del Código Civil Argentino, 3 Anales de la Academia de Derecero y Ciencias Sociales DE CóRdoBa 111 (Argentina 1945). 
Prussian Code of Civil Procedure of 1793 which originally had that rule; ${ }^{52}$ but an amendment of 1798 not noted in the work had restricted application of the rule to cases where a differentiation of this kind is made in the foreign law, thus maintaining the rule as a measure of retaliation only. ${ }^{53}$

The rule in the Codes of Argentina, Paraguay, Peru, and Uruguay, which gives resident creditors a priority in the case of concurrent bankruptcies, has been the subject of constant criticisms; eminent South American lawyers have been no less critical than foreign lawyers and foreign courts. ${ }^{54}$ At an early stage, Ernesto Quesada ${ }^{55}$ and Carlos Calvo ${ }^{56}$ were among those expressing their disapproval; of the more recent criticisms, a paper read in 1925 by Dr. Carlos Alberto Alcorta before the Argentine Branch of the International Law Association has become widely known. ${ }^{57}$

Of the leading commentators in the countries which have the rule, ${ }^{58}$ some criticize the rule without reservation; others wish to have the rule retained for the protection of local creditors against similar practices abroad, an argument which would suggest a limitation in the application of the rule similar to that made in 1798 in Prussia. The argument has been made that without the rule local creditors could suffer damage from foreign exchange regulations which may freeze the dividends available abroad. However, application of the hotchpot rule would be fully sufficient to protect the local creditors in such cases. Some commentators assert that the priority right obtains for all claims payable within the country, even when held by non-residents. On the other hand, some contend that the priority rule is applicable not only in concurrent bankruptcies, but also when bankruptcy has been declared only abroad. Early commentators ${ }^{59}$ have

52. Code of Civil Procedure, 1793, part I, title 50, §665.

53. Appendix to the Code, \$379, added by Decree of Sept. 24, 1798, Novum Corpus Constitutionum Prussico-Brandenburgensium, 1798, p. 1758.

54. For a foreign court, see, e. g., Appeal Genoa, Oct. 25, 1891, Ditta Rivara e C. v. Duglio e Bisleri, [1892] ANNALI DELLA GIURISpRudenza Italiana, III. 15, 44 GiURISPRUDENZA ITALIANA, I(2). 200 (1892).

55. Quesada, Estudios Sobre Quiebras (Buenos Aires 1882) (with preface by Almancio Alcorta). Cf. 3 Almancio Alcorta, Curso de Derecho Internacional PrIVAdo 401 (2d ed., Buenos Aires 1927).

56. 2 Calvo, Droit International, No. 911 (5th ed., Paris 1896).

57. C. A. Alcorta, Régiment Internacional de la Quiebra, 14 JuRrSpRudencia ARgentina, Part: Doctrine, p. 130 (1924), 2 Revista ARgentina DE Derecho InTERnacional 354 (1931) , 4 Vico, Curso de Derecho Internacional Privado 34 (2d ed., Buenos Aires 1939).

58. See those referred to or quoted in 2 Victor N. Romrero del Prado, Manual De Derecho Internacional Privado 554, 569 et seq. (Buenos Aires 1944); works listed notes 43 to 46 sipra; 1 Francisco García MARTINEz, EI Concordato $\mathrm{Y}$ LA Quiebra en el Derecho Argentino y Comparado 138 (Buenos Aires 1940) ; 2 Francisco Orione, Ley de Quiebras 331 (Buenos Aires 1935); 5 Mario A. Rivarola, Tratado de Derecho Comercial Argentino, \$1409 (Buenos Aires 1940).

59. Lisandro Segovia, Explicación y Critica del Nuevo Código de Coniercio, note 4455, under section 1385 (Buenos Aires 1892). Cf. Manuel Obarrto, Estudio SOBRe las QuiEbras, No. 30 (Buenos Aires 1895). 
considered exclusively instances where the debtor has two establishments, one at home and one abroad.

While Argentina, Paraguay, Peru, and Uruguay have maintained unchanged in their statute books the rule under discussion, they do not apply the rule in their mutual relations. Together with Bolivia and Colombia, they are all partners to the treaty of Montevideo of 1889 on international commercial law which provides different rules.

\section{V}

When the International South-American Congress convened in Montevideo in 1888 , it had before it a draft prepared by a Committee appointed by the South-American Congress of Jurists which had met in Lima in 1877. The Lima draft ${ }^{60}$ followed closely Fiore's ideas, admitting concurrent bankruptcies only in the case of "distinct and separate establishments". The Congress of Montevideo chose a different approach suggested by Gonzalo Ramírez, of Uruguay, who was the reporter on the bankruptcy subject.

The Treaty of Montevideo of 1889 on International Commercial Law ${ }^{61}$ distinguishes for jurisdictional purposes between the case where a debtor has "independent commercial houses" in different countries and all other cases. In the first eventuality, as many bankruptcies may be declared as independent houses exist in different countries; in all other cases, the court of the commercial domicile of the debtor is given exclusive bankruptcy jurisdiction. When bankruptcy is declared in one country and assets are located in another, measures for the protection of the local assets shall be taken in that country. The bankruptcy adjudication abroad is published locally and local creditors are given the right to ask for a local bankruptcy adjudication. When that right is used, the two proceedings are conducted entirely separately. For the purpose of determining which claims belong to each bankruptcy, the treaty indicates that "local creditors" means those with claims payable in the country of the proceeding. ${ }^{62}$

60. Draft of 1881 for a treaty of international commercial law, $\$ \$ 22-30$, with report by Antonio Arenas of Peru, in 2 Congresos Americanos DE Lima 402, 408 (Lima 1938).

61. Treaty, $\S 35-48$, Actas y Tratados Celebrados por el Congreso InternaCIONAL SUd-AMericano dE Montevideo 842 (Montevideo ed. 1911), Report of THE INTERNational AMERICAN CONGREsS 876 (Washington 1890), 24 Journal DU Droit International 900 (Paris 1897). Comments on the treaty in all treatises on private international law by South American lawyers; also: C. A. Alcorta, El Profesor Meili y el réginnen de la quiebra en el Congreso Sied-Americano de Montevideo, 14 Jurisprudencia Argentina, Part: Doctrine, p. 66 (1924); F. Memi, MoDERNE STAATSVERTRÄGE ÜBER DAS INTERNATIONALE KONKURSRECHT (Zurich 1907); F. MeILT, Lemrbuch DES INTERNATIONALEN KonkurSRECHTS (Zurich 1909); Wyndham A. Bewes, The Treaties of Montevideo, 6 Transacrions of the Grotius Society 59, 69, 78 (England 1921).

62. Sections 39 and 40 of the treaty. 
A controversy has developed over the right of the local creditors to ask for a second bankruptcy adjudication. Some say that this right applies only in cases where an independent house is located within the country; others assert that the right exists whenever assets are in a country other than that of the bankruptcy declaration. Both sides rely on the language of the treaty and the report which Gonzalo Ramírez submitted to the Montevideo Congress. ${ }^{63}$ The opposing views were argued indecisively in Montevideo in 1939 and 1940 when the treaty of 1889 was revised by the Second South-American Congress of Private International Law. ${ }^{64}$

One of the tasks set forth for the Second Montevideo Congress of 1939 was to provide rules for non-commercial bankruptcies. A draft prepared by the Argentine Institute of International Law ${ }^{65}$ for that purpose gave local creditors the right to ask for another bankruptcy whenever assets are located outside the country of the domicile of the debtor. When this right is used, creditors with claims payable within the country were given a right of priority of payment in regard to the local assets. ${ }^{66}$ The argument made in support of this priority right was that a local creditor may have contracted "in view of the local solvency" of the debtor, ${ }^{67}$ an argument previously encountered in connection with the "separate establishment" doctrine only. The Institute of International Law of Uruguay went one step further and insisted on broadening the priority rule so that it would be applicable in all instances, even when no second bankruptcy is declared. ${ }^{68}$ The new Montevideo Treaty of 1940 on International Civil Procedure, which contains the rules for non-commercial bankruptcies, provides accordingly. Creditors with claims payable in the country of the location always have a right of priority of payment out of the local assets. ${ }^{\text {e9 }}$

63. Actas y Tratados, op. cit. supra note 61, at p. 676.

64. Minutes of the March 15, 1940 Session of the Commission on International Commercial Law, in Actas de la Reunión de JuRisconsultos; Segunda Etapa, Docunientación Provisoria (Montevideo 1940) ; Comisión de Derecho Contercial InTERnactonaL, Acta No. 3, p. 7.

65. Draft for a treaty on international civil procedural law, $\$ 16-25,2$ Revista Argentina de Derecho INTERnacional 247 (1939), 15 ReVISTA JURídica ArgentiNa LA LEY, Part: Legislation, p. 112 (1939).

66. Section 20(2) of the draft. According to Videla Aranguren, El Concurso Civil de Acreedores en el Congreso de Montevideo 1939-40, in 4 Revista Argentina DE DERECHO INTERNACIONAL 214, No. 30 (1941), the insistence of the members of the Institute of Uruguay to maintain the legal principles of the old treaty is responsible for the draft.

67. Videla Aranguren, El Derecho Procesal y el Congreso de Montevideo, 2 Revista Argentina de Derecho Internactonal 311, No. 20 (1939).

68. See Videla Aranguren, loc. cit. supra note 67, at p. 312, note 19.

69. Section 20, Tratado de Derecho Procesal International, 1940, in Segundo Congreso Sudamericano de Derecho Internacionaz PrIvado, Acta Final 41 (2d ed., Montevideo 1940), 18 Revista Juridíca Argentina LA LeY, Part: Legislation, 3 (1940); 37 ANr. J. INT'L. L. SUPP. 116 (1943). 
The rules of the treaty are made applicable to arrangement (composition) proceedings. ${ }^{70}$

The new Montevideo Treaty of 1940 on International Terrestrial Commercial Law, which deals with commercial bankruptcies, was brought into line with the treaty on International Civil Procedure. Upon the proposal of the delegate from Uruguay, made at the Congress, a new provision was added to the text of the treaty of 1889 . This provision gives the holder of a claim a right of priority of payment out of the assets located in the country of the place of payment even when only one bankruptcy is declared. ${ }^{71}$ Most of the provisions of 1889 have been taken over unchanged. The rules are now made applicable to arrangement proceedings also. ${ }^{72}$ The question remains whether the right to ask for a second bankruptcy applies in all instances, or only in the case of independent houses. In signing the treaty, Brazil has made the reservation that the right shall exist in all instances.

The new rule which grants a right of priority of payment even when only one bankruptcy is declared, was opposed at the Congress by the Argentine delegates. ${ }^{73}$ It has since been criticized by a number of writers. ${ }^{74}$ Doctor Quintin Alfonsín, of Montevideo, in his comprehensive work on the doctrine of Montevideo and the treaties of 1889 and $1940,{ }^{75}$ considers the new system a distortion of the true doctrine of Montevideo. Its practical workability may be questioned especially with respect to arrangement proceedings. Only Uruguay has so far ratified the new treaties. ${ }^{75 a}$

It is interesting to note that the definition of "local claim" in the treaty of 1889 , now the basis for a new local priority rule, became the subject of a controversy immediately after the Congress of 1889 . The treaty of 1889 , it may be recalled, contains no priority provision; it only regulates the assignment of claims to the respective estates in the case of concurrent bankruptcies. Lisandro Segovia, in his work on the Montevideo Congress published in 1889, called the "place of pay-

70. Section 25 of the treaty.

71. Section 48(2), Tratado de Derecho Comercial Terrestre Internacional, 1940, in SEgundo Congreso, op. cit. supra note 69, at p. 61, Revista LA LEX, supra note 69, at p. 17; AM. J. INT'L. X., stupra note 69, at p. 132. Cf. Videla Aranguren, Las Quiebras en el Congreso de Montevideo, 1939-1940, 5 Revista ARgenTINA DE DERECHO INTERNACIONAL 448 , No. 45 (1942).

72. Section 53 of the treaty.

73. Minutes of Sessions of July 25, 1939, and August 1, 1939, Commissions on Procedural and Commercial Law, respectively; minutes of March 14, 1940 session, note 64 supra.

74. E.g., 2 Victor N. Romero del Prado, Manual de Derecho Internactonal Privado 585, 963 (Buenos Aires 1944); Videla Aranguren in Revista Argentina de DERECHO INTERNACIONAI, vol. 4 at $342^{\prime}$ (1941), and vol. 5 at 450 (1942).

75. Quintin Alfonisin, Quiebras-La Doctrina de Montevmeo y los TrataDOS DE 1889 y 1940, 135 (Montevideo 1943).

75a. Law No. 10,272 of 1942 . 
ment" criterion used in the treaty improper as a means of separating claims of independent houses. ${ }^{76}$ Gonzalo Ramirez, in his reply, stressed that the provision was needed and gave as an example the case of a debtor with houses in Rio and Montevideo who owes a noncommercial debt not connected with either house. Commentators of the Roman Law rule, however, had held claims not connected with any of the establishments provable in all distributions. ${ }^{77}$ Gonzalo Ramírez pointed further to the fact that the place of payment criterion was used in the same way in the treaty of Montevideo of 1889 on International Civil Law in the matter of decedents' estates ${ }^{78}$ where priority rights are granted on the local assets to "local claims", $i$. e., claims payable at the location of the assets. ${ }^{79}$ The priority rule had been adopted for that treaty against the opposition of Chile. ${ }^{80}$ The argument made in support of the priority right was that "it is based on the same principles which account for the analogous provision of the Argentine Code of Commerce in matters of bankruptcy". ${ }^{81}$ Thus all seems to revert to the priority rule in the Code of 1859 for the Province of Buenos Aires which became the rule of the Argentine Code of Commerce.

The insertion in the treaties of 1940 of the new clause granting "local claims" priority rights on the local assets in all circumstances has brought out the fundamental issue which is the propriety of priority rights outside the case of independent houses. The question whether a second bankruptcy declaration is needed for the exercise of the priority right, is, compared with this, a side issue. The turn which the Montevideo Congress of 1939-1940 has taken towards the strengthening of local priority rights seems to have surprised many. If one judges from the modern writings on the Conflict of Laws in South America, the trend seems to go just in the opposite direction. Peru's representative at the Congress, Dr. Bustamante y Rivero, has stressed the fact that the Congress of 1939 was to commemorate the Congress held 50 years before, and that Uruguay was not prepared to sacrifice

76. Segovia, El Derecho Internacional Privado y el Congreso Sud-AmertCano de Montevideo 162 (Buenos Aires 1889).

77. Paulus Castrensis (d. 1441), Commentaria in Dig. Vetus, Part 2, De

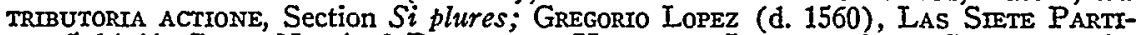
Das 5.14.11, GLoss No. 4; 2 Dominguez Vincente, Irustración y Continuación A la Curia Firfírica, C. XII, No. 59 (Madrid 1790).

78. Gonzalo Ramírez, Ex Derecho Procesal Internactonal en el Congreso de Montevideo (Montevideo 1892). Cf. C. A. Alcorta, El Profesor Meili, loc. cit. supra note 61 , at p. 72 .

79. Treaty on International Civil Law, 1889 , $\$ \$ 46-48$, Acras y Tratados, op. cit. supra note 61 , at 827,23 Journal DU Drort INTERNATIONAd 446 (1896). This was kept unchanged in the Treaty on International Civil Law, 1940, \$\$ 46-48, SEgundo CoNGRESo, op. cit. supra note 69, at 73, 37 AM. J. INT'L. L. SuPP. 141 (1943). at 518 .

80. Belisario Prats, speaking for Chile, Actas y Tratados, op. cit. supra note 61,

81. Manuel Quintana of Argentina, speaking for the majority, at 498. 
what has become known as the doctrine of Montevideo. ${ }^{82}$ Peru's position in this respect is of special interest because Peru is also a co-signatory of the Bustamante Code with its very different approach to the problem.

Provisions in a treaty may affect the rights of creditors inside as well as outside the treaty group. For the creditor from the outside, it makes no difference whether he loses his equal share because of a statutory priority provision or because of the effects of a treaty which prescribes the disposition of the assets within the treaty group in a certain way. This makes local priority rules the concern of all, whether they are contained in a treaty or in a statute.

\section{VI}

What are the practical consequences of local priority rules? A business man from abroad will not give open credit when he knows that, in the case of bankruptcy of his debtor, he may not receive his equal share because of the possible operation of some local priority rule. When he learns that priority rights are granted on the assets which are at the "place of payment", he will no doubt insist on a contract clause which makes "place of payment" all places where assets of the debtor are located.

Foreign trade has its own opinion of local priority rules. Any departure from the principle of creditor equality is watched with distrust and considered an additional hazard with which to cope. Business circles know where such rules exist. Credit Men associations warn their membership. Consequently, creditors from abroad will be found sparingly among the unsecured creditors in failures in countries with a local priority rule. Paradoxical as it may sound, local priority rules, when known, rather protect the creditor from abroad. A statistical survey may be revealing in this connection.

Local priority rules are a matter of concern not only to the business man and his adviser; economists also see in them an unhealthy development. Because of the cautious attitude of foreign trade, transactions which could be made do not take place. If credit is extended, it is only upon terms compensating for the exceptional risk. Such terms are easily a source of irritation. On the other hand, damage suffered from the application of a local priority rule has a devastating effect on trade relations.

These rules have all the characteristics of trade barriers. They have been included as such in the discussions currently under way in

82. Bustamante y Rivero, El Tratado de Derecho Civil Internacional de 1940, 2 Revista Peruana de Derecho Internacional 232 (1942); see also pp. 386-7 for Peru's reservations. 
connection with preparatory work for the creation of an International Trade Organization. Leading organizations in the United States have urged their Government to see that a "creditor equality clause" is included in the Charter for the International Trade Organization. ${ }^{83}$ The International Chamber of Commerce has taken a similar stand with respect to the protection of foreign investments. ${ }^{84}$

It is not without interest to read what was said early in this century in the Congress of the United States in a debate on the merits of the national bankruptcy legislation: "The law has done more to increase the credit of the poorer sections of this country than any law that was ever put upon the statute books . . . Because it gives assurance to the foreign creditor, if he lends to a merchant and misfortune overcomes that merchant, that he will have an equal chance with the home creditor. The fact that the distant creditor knows that he is on equal footing with every other creditor as to their debtor warrants him in extending credit that he never would extend otherwise, and did not extend prior to that law". ${ }^{85}$ Indeed, no sound credit system can be thought of without "creditor equality" as the basis. The experience of centuries is embodied in the rule written into the Code Napoleon that "the whole property of the debtor is a common pledge for all his creditors".86

\section{VII}

The rules which govern the admission of claims in the case of concurrent bankruptcies show a lack of uniformity in American laws which is alarming, considering the fact that these rules are of substantial importance to inter-American commercial relations. Under one system, all creditors are paid on a strict equality basis. A variation provides for a separation of creditors in the case of distinct and separate establishments. In numerous countries, on the other hand,

83. 16 Dep't. State Bull. 724 (1947) (National Bankruptcy Conference); 49 Credit and Financral Managearent, No. 4, at 28 (April 1947) (Foreign Credit Interchange Bureau, National Association of Credit Men); 21 J. N. A. REF. BANKR. 127, 52 Com. L. J. 89 (1947) (Committee on Bankruptcy, Commercial Law League of America).

84. International Chamber of Commerce, Brochure No. 107 on Foreign Investments and Economic Expansion, at 20 (March 1947); 11th Congress of the International Chamber of Commerce (Montreux 1947), Resolution No. 9. Cf. Geneva Draft of the Charter for an International Trade Organization of the United Nations, Art. 11(3): "The Organization may make recommendations for and promote international agreement on measures designed to assure just and equitable treatment for the enterprise, skills, capital, arts and technology brought from one Member country to another, including the elaboration and adoption of a general agreement or statement of principles as to the conduct, practices and treatment of foreign investment." U. S. CoM. Policy Ser., No. 106, at 12 (Dep't. State 1947); 17 Dep't. State Bull. 663,669 (1947).

85. 45 CoNG. REc. 2273 (1910) (Congressman Shirley of Kentucky), quoted by MeLaughlin in 60 HARv. L. Rev. 234 (1946).

86. Code Napoleon, §§ 2092, 2093. 
differences are made between creditors. The type of creditors preferred varies; among the distinctions employed are nationality, place of residence, place of contracting, place of payment.

It is important to have the problem created by these differences in the law brought into the open. This is the safest way to bring it to a solution. The situation may seem hopelessly embroiled, yet similar conditions were known previously, and it was possible to remedy the situation. The history of bankruptcy law, full of international ${ }^{87}$ and interstate ${ }^{88}$ incidents, is instructive in this respect. There was a time when the creditors from abroad were paid first; codes and commercial treaties of the 12th and 13th century testify to that fact. $^{89}$ It is not necessary to fall into the other extreme in the search for a fair and equitable solution.

The maintenance of rules which favor the domestic creditor is as much a local as it is an international issue. Often, opinions on the subject are widely split domestically. Considerations enter into the debate that are outside the legal field. All that the legal profession can do is to clarify as much as possible the legal side of the issue. Local literature on the individual priority rules is abundant; the status of the law on the subject in other countries is, however, rarely given. This makes it difficult to get a full view of the situation. Only on the basis of complete information can one properly assess how an individual rule fits into the common system, and how far the rule keeps in line with the general evolution of the law. ${ }^{90}$

87. The well-known incident of 1784 between France and Switzerland is related by C. A. Alcorta, loc. cit. supra note 57. Cf. Lévy-Bruhl, Recherches sur la réglementation internationale des faillites au 18 e siècle, 33 REVUE CRITIQUE DE DROIT INTERNATIONAL 175 (France 1938), on this and other incidents. For an incident between the Imperial Cities of Ulm and Biberach, see Camera Imperialis, Oct. 21, 1591, Creditors of Craefft (or Krefft), 3 Decisiones Rotae SpIRENsis, No. 197 (Casp. Guilh. Scipio ed. 1602), referred to in Joh. N. Hertius, De collisione legum dissertatio, Sec. IV, No. 64, 1 CoMMENTATIONES ET OPUSCULA 150 (Frankfort 1737). An incident between the City States of Venice and Florence of 1326 in the bankruptcy of the Pilestri is mentioned in 6(2) Pertile, Storia DEL Diritio Italiano 403, n. 106 (2d ed. Turin 1902).

88. Numerous were the differences between England and its American Colonies. 1 Gramame, History of the United States of AMerica, App. I, p. 560 (1856). For an American interstate conflict, see Blake v. McClung, 172 U. S. 239 (1898), supra note 8. Interprovincial difficulties in Argentina before the enactment of the Jurisdictional Act of Sept. 9, 1878, Registro Nacional, No. 11099, are noted in RaMoN M. Alsina, RÉgIMEN de la QuIEBra EN EL ORDEN Internacional 302 (Buenos Aires 1909).

89. See Ordinances of Iaroslav, 1113-1125, Art. 55, in Mediaeval Russian LAws 46 (Vernadsky trans. 1947), 1 KaRAMSIN, HISTOIRE DE L'EMPIRE DE RUSSIE 69 (Paris 1819). German-Russian 'TREATIES of: Novgorod, 1268-69, § 18, Smolensk, 1229 , $\$ \$ 5,7$, Smolensk, 1250 , $\$ 7$, 9, in GoETz, DeUTSCH-RUSSISCHE HANDELSVERTRÄGE DES MTTTELALTERS 144, 246, 308 (Hamburg 1916).

90. For recent material on international bankruptcy law, see, e. g., Gruliano, II Fallimento Nel Diritro Processuale Civile Internazionale $349^{\circ}$ et seq. (Milan 1943) ; Nadelmann, The Recognition of American Arrangements Abroad, 90 U. of Pa. L. Rev. 780 (1942), 29 Revista JuRf́dca Argentrna La Ley 888 (Aranguren and Thamis trans. 1943); Nadelmann, International Bankruptcy Law: Its Present 
Comparisons clear the way to greater uniformity of the law; they "contribute advantageously to the formation of a collective conscience".91 Organizations like the Inter-American Bar Association help substantially in this respect. They furnish a forum for the exchange of information and a discussion of divergent views. The survey here submitted is incomplete and has the bias, if bias it is, to be written from the viewpoint of creditor equality. ${ }^{92}$ Other studies, it is hoped, will supplement and correct, where necessary, the material presented. After a full coverage of the subject, the possibilities for greater uniformity will appear automatically. The problem here raised and the broader question of the treatment of foreign and nonresident creditors in bankruptcy ${ }^{93}$ are important enough, it is believed, to be made a special topic for discussion at a Conference of the Association.

Status, 5 U. of Toronto L. J. 324 (1944) ; Nadelmann, supra note 42; Rodriguez Quesada, Aspecto Internacional de la Quiebra, 4 RevisTa DE DeRECHO PUBLICo Y PRIvado 67, 131 (Uruguay 1941) ; 7 Travers, Droit Comarerctal International (Paris 1935, 1936); Valensi, Faillite in 8 RéPERTOIRE dE DroIt INTERNATIONAL 286 (De Lapradelle and Niboyet ed., Paris 1930).

91. Alberto M. Justo, Conciencia Juridica Interamericana, 26 Revista Jurídica Argentina La Ley 1045 (1942).

92. The principle of creditor equality should no doubt be considered in connection with the progressive development and the codification of international law (U. N. Charter, Art. 13, \$(1)(a)). Cf. Jessup, The Subjects of a Modern Law of Nations, 45 Micr. L. REv. 383, 402 (1947).

93. Cf. Nadelmann, Legal Treatment of Foreign and Domestic Creditors, 11 LAw \& Contemp. Prob. 697 (1946). 